\title{
Cytotoxic and anthelmintic potential of crude saponins isolated from Achillea Wilhelmsii C. Koch and Teucrium Stocksianum boiss
}

\author{
Niaz Ali*, Syed Wadood Ali Shah², Ismail Shah², Ghayour Ahmed², Mehreen Ghias² and Imran Khan³
}

\begin{abstract}
Background: Saponins isolated from plant sources have a number of traditional and industrial applications. Saponins have pharmacological effects like anti-inflammatory, molluscicidal, antimicrobial, antispasmodic, antidiabetic, anticancer, anticonvulsant, anthelmintic, antitussive and cytotoxic activities. The current work describes the anthelmintic and cytotoxic activities of crude saponins of Achillea Wilhelmsii and Teucrium Stocksianum as these plants are rich with saponins.

Methods: Brine shrimp cytotoxic activity of crude saponins was determined by Meyer et al. (1982) at test concentrations of $1000 \mu \mathrm{g} / \mathrm{ml}, 100 \mu \mathrm{g} / \mathrm{ml}, 10 \mu \mathrm{g} / \mathrm{ml}, 7.5 \mu \mathrm{g} / \mathrm{ml}, 5.0 \mu \mathrm{g} / \mathrm{ml}, 2.5 \mu \mathrm{g} / \mathrm{ml}$ and $1.25 \mu \mathrm{g} / \mathrm{ml}$. Percentage mortality of test concentrations was determined. Similarly, in vitro anthelmintic activity was determined against roundworms, tapeworms and earthworms. Albendazole and piperazine citrate at concentration $10 \mathrm{mg} / \mathrm{ml}$ were used as standard anthelmintic drugs.

Results: Crude saponins of Achillea wilhelmsii (CSA) and Teucrium stocksianum (CST) had, respectively, cytotoxic activity with $L C_{50}$ values $2.3 \pm 0.16$ and $5.23 \pm 0.34 \mu \mathrm{g} / \mathrm{ml}$. For in vitro anthelmintic activity, time for paralysis and death of parasites (parasiticidal activity) was noted. At concentration $40 \mathrm{mg} / \mathrm{ml}$, crude saponins of Achillea wilhelmsii are 1.96 and 2.12 times more potent than albendazole against Pheretima posthuma and Raillietina spiralis, respectively. Similarly, at concentration $40 \mathrm{mg} / \mathrm{ml}$, crude saponins of Teucrium stocksianum (CST) has 1.89, 1.96 and 1.37 times more parasiticidal activity than albendazole against Pheretima posthuma, Raillietina spiralis and Ascardia galli, respectively.

Conclusion: Crude saponins of Achillea wilhelmsii and Teucrium stocksianum have cytotoxic and anthelmintic activity. The crude saponins may be excellent sources of cytotoxic and anthelmintic constituents that warrant its isolation and purification for new drug development.
\end{abstract}

\section{Background}

Saponins are a large family of structurally related heterosides compounds of steroid or triterpenoid aglycone (sapogenin) linked to one or more oligosaccharide moieties by glycosidic linkages. The carbohydrate moiety consists of pentose(s), hexose(s) or uronic acid(s) [1,2]. Saponins are classified, according to their aglycone skeleton, as non-steroidal saponins, steroidal saponins and steroidal amines that are also referred to as steroidal alkaloids [3].

\footnotetext{
* Correspondence: niazpharmacist@yahoo.com

${ }^{1}$ Department of Pharmacology, Institute of Basic Medical Sciences, Khyber

Medical University, Peshawar, KPK, Pakistan

Full list of author information is available at the end of the article
}

Saponins have a number of traditional and industrial applications [4-6]. Saponins from plants sources are also responsible for some pharmacological effects like antiinflammatory [7], molluscicidal [8], antimicrobial [9], antispasmodic [10], antidiabetic and anticancer [11], hypocholesterolemic [12], antioxidant [13], anticonvulsant and analgesic [14], anthelmintic, antitussive and cytotoxic activities [15].

Achillea wilhelmsii (Local name: Zawal) belongs to Asteraceae, which contains alkaloids, flavonoids, terpenoids, volatile oils, sesquiterpenelactones and saponins [16]. While Teucrium stocksianum belongs to family Lamiaceae, which contains phytochemicals like carbohydrates, proteins and amino acids, tannins, flavonoids,

\section{C) Biomed Central}


sterols and saponins. It gave negative tests for alkaloids, anthraquinone glycosides and cardiac glycosides [17]. Based on the reported literature for different saponins as cytotoxic and anthelmintic agents, the current work is carried out to screen the crude saponins of Achillea wilhelmsii and Teucrium stocksianum for possible cytotoxic and anthelmintic activity.

\section{Methods}

\section{Plant Materials}

Plant Achillea wilhelmsii was purchased from the local market of Nasir Bagh, Board district Peshawar, KPK. Teucrium stocksianum was collected from nearby hills of University of Malakand in the month June - July 2009. The plants were authenticated by Professor Dr. Jehandar Shah, vice chancellor Shaheed Benazir Bhuto University, Sheringal Dir Upper, KPK. Voucher specimens, respectively, AW-2009 for Achillea wilhelmsii and T-01-2009 for Teucrium stocksianum were deposited in the herbarium of Department of Botany, University of Malakand. Ethical Committee of the department of pharmacy approved the experimental protocols as per animal byelaws 2008 of the University of Malakand "Scientific Procedures Issue I".

\section{Preparation of extract and the crude saponins}

170 grams of powdered materials of aerial parts of Achillea wilhelmsii and Teucrium stocksianum were extracted with petroleum ether by successive extraction in Soxhlet apparatus followed by extraction with commercial grade methanol. The solvents were subjected to rotary evaporation under vacuum to obtain dry semi solid extracts. The methanol extracts of both plants were further fractionated with $n$-butanol and water, in equal proportion, to get the $n$-butanol fraction. The crude saponins were precipitated with ether yielding $12.35 \mathrm{~g}$ of crude saponins of Achillea wilhelmsii (CSA) and $9.80 \mathrm{~g}$ of crude saponins of Teucrium stocksianum (CST) [18].

\section{Drugs and chemicals}

All the reagents used were of analytical grade (E. Merck). Piperazine citrate (GSK) and albendazole (GSK) were used as standard reference drugs in the experiments at concentration $10 \mathrm{mg} / \mathrm{ml}$.

\section{Statistical analysis and calculations}

Statistical analysis was performed at 95\% confidence interval. $\mathrm{P}$ value equal to or less than 0.05 was considered as significant. Microsoft XL sheet and Graph Pad prism were used to calculate mean, SEM and draw the curves for $\mathrm{EC}_{50}$ and $\mathrm{LC}_{50}$.

\section{Brine Shrimp Cytotoxicity}

Brine shrimp cytotoxic activity of crude saponins was determined as described by Meyer et al. (1982) with some modifications. Briefly describing, brine shrimp eggs
(Artemia salina) were placed on one side of a small tank which was filled with sea water, covered with aluminum foil, and fully aerated. After $48 \mathrm{~h}$ incubation at room temperature and under illumination, the resulting nauplii (larvae) were attracted to the other side of the tank with a light source. The nauplii were collected with the help of a dropper.

Stock solutions $(10 \mathrm{mg} / \mathrm{ml})$ of CSA and CST were prepared by dissolving $20 \mathrm{mg}$ of each sample in $2 \mathrm{ml}$ of methanol. From the stock solution, $1000 \mu \mathrm{g} / \mathrm{ml}, 100 \mu \mathrm{g} /$ $\mathrm{ml}, 10 \mu \mathrm{g} / \mathrm{ml}, 7.5 \mu \mathrm{g} / \mathrm{ml}, 5.0 \mu \mathrm{g} / \mathrm{ml}, 2.5 \mu \mathrm{g} / \mathrm{ml}$ and 1.25 $\mu \mathrm{g} / \mathrm{ml}$ were prepared by taking $500 \mu \mathrm{l}, 50 \mu \mathrm{l}, 5 \mu \mathrm{l}, 3.75 \mu \mathrm{l}$, $2.5 \mu \mathrm{l}, 1.25 \mu \mathrm{l}$ and $0.625 \mu \mathrm{l}$, respectively. The solvents were evaporated from the vials by exposing to evaporation for 24 hours. $2 \mathrm{ml}$ of sea water was added and ten brine shrimps nauplii were transferred with the help of a dropper to each sample vial and the volume of sea water was adjusted to $5 \mathrm{ml}$. Negative control experiments contained $5 \mathrm{ml}$ of sea water and ten brine shrimps. Survivors were counted after $24 \mathrm{~h}$ [19]. Percentage mortality of test concentrations and control was determined using the equation: \% mortality $=$ (no. of dead nauplii/initial no. of live nauplii) $\times 100$. Experiments for each concentration were performed in triplicate.

$\mathrm{LC}_{50}$ values less than $100 \mathrm{ppm}(100 \mu \mathrm{g} / \mathrm{mL})$ were considered significant.

\section{Anthelmintic activity}

Adult roundworms (Ascaridia galli), tapeworms (Raillietina spiralis) and earthworms (Pheretima posthuma L. Vaill) were used to evaluate in vitro anthelmintic activity. The earth worms were collected from swampy water near the new boys' hostel, University of Malakand, Dir, KPK, Pakistan. Roundworms and tapeworms were obtained from the intestines of freshly slaughtered fowls. Their intestines were treated with normal saline solution to remove all the fecal matters. The worms were collected after dissection of intestines and maintained in normal saline solution, having an average size of roundworms, tapeworms and earthworms as 5-7 cm, 6-7 $\mathrm{cm}$ and 7-8 $\mathrm{cm}$, respectively. The assay was performed by using adult earthworms in vitro because the earthworm has high resemblance, both anatomically and physiologically, with the intestinal roundworm parasite Ascaris lumbricoides of human beings. The prelabeled extracted saponins from both plants were prepared in distilled water at concentrations of 10, 20 and $40 \mathrm{mg} / \mathrm{ml}$. Six worms, approximately of equal size, each of Pheretima posthuma, Raillietina spiralis and Ascaridia galli, were placed in petri dishes. Each petri dish contained $25 \mathrm{ml}$ of test solution of the extracts. For reference standards, Albendazole and Piperazine citrate (10 $\mathrm{mg} / \mathrm{ml}$ each) were used as positive controls, and distilled water was used as the negative control.

The experiments were run in triplicate. Before starting the experiments, standard drugs and test solutions were 
freshly prepared. Time for paralysis was recorded when no movement was observed except when shaken vigorously, whereas time of death was recorded when the worms did not show any movement by vigorous shaking nor when dipped in warm water $\left(50^{\circ} \mathrm{C}\right)$ [20].

\section{Results and discussion}

Crude saponins of Achillea wilhelmsii (CSA) were very potent and killed all the shrimps at concentrations 1000, 100, 10 and $7.7 \mu \mathrm{g} / \mathrm{ml}$ (Table 1). Plotting concentration response curves for $5,2.5$ and $1.25 \mu \mathrm{g} / \mathrm{ml}, \mathrm{LC}_{50}$ value is $2.30 \pm 0.16 \mu \mathrm{g} / \mathrm{ml}(\mathrm{n}=3)$ (Figure $1 \mathrm{~A}) .100 \%$ cytotoxic activity was shown by crude saponins of Teucrium stocksianum at test concentrations 1000 and $100 \mu \mathrm{g} / \mathrm{ml}$ (Table 1). Similarly, plotting concentration response curves for CST at concentrations 10, 7.5, 5.0 2.5 and $1.35 \mu \mathrm{g} / \mathrm{ml}, \mathrm{LC}_{50}$ was $5.23 \pm 0.34 \mu \mathrm{g} / \mathrm{ml}$ (Figure $1 \mathrm{~B}$ ). While comparing the $\mathrm{LC}_{50}$ values, it is evident that crude saponins of Achillea wilhelmsii were more potent (more than 2 times) than crude saponins of Teucrium stocksianum. Hence, it is deduced that the crude saponins of both species have cytotoxic constituents. Based on the previous literature reports for positive correlation between the brine shrimp cytotoxicity assay and human KB cell line (human nasopharyngeal carcinoma), the current work warrants for isolation of these anticancer constituents present in the plants [21].

Results for anthelmintic activity against the test parasites are mentioned in Table 2. The crude saponins of Achillea wilhelmsii showed dose dependent response against the test parasites. Time for paralysis and death (parasiticidal activity) are shown in Table 2. The crude saponins of Achillea wilhelmsii showed comparable efficacy to piperazine citrate against Pheretima posthuma at concentration $20 \mathrm{mg} / \mathrm{ml}$. Quantifying the effects as \% of albendazole, the results are expressed in Figure 2. At concentration $40 \mathrm{mg} / \mathrm{ml}$ of crude saponins of Achillea wilhelmsii, the parasiticidal activity is 1.96 and 2.12 times more potent than albendazole against Pheretima posthuma and Raillietina spiralis, respectively. Against Ascaridia galli, the parasiticidal activity was comparable with albendazole at concentrations 10 and $20 \mathrm{mg} / \mathrm{ml}$; however, at concentration $40 \mathrm{mg} / \mathrm{ml}$, activity was 1.32 times that of albendazole (Figure 2). Similarly, at concentration $40 \mathrm{mg} / \mathrm{ml}$, crude saponins of Teucrium stocksianum have 1.89, 1.96 and 1.37 times parasiticidal activity of albendazole against Pheretima posthuma, Raillietina spiralis and Ascaridia galli, respectively (Figure 3). From the above results, it is clear that the crude saponins of Achillea wilhelmsii and Teucrium stocksianum have excellent anthelmintic activity. Other interesting findings of the study are that albendazole and piperazine citrate have comparable in vitro efficacy against the test parasites.

\section{Conclusion}

Crude saponins of Achillea wilhelmsii and Teucrium stocksianum have cytotoxic and anthelmintic activity. The crude saponins may be excellent sources of cytotoxic and anthelmintic constituents that warrant their isolation and purification from the medicinal plants for a more thorough investigation.

Table 1 Brine shrimp cytotoxicity of crude saponins of Achillea wilhelmsii and Teucrium stocksianum

\begin{tabular}{|c|c|c|c|c|}
\hline Sample & $\begin{array}{l}\text { Conc. } \\
(\mu \mathrm{g} / \mathrm{ml})\end{array}$ & No of brine shrimps taken & No of brine shrimps killed & $\mathrm{LC}_{50}(\mu \mathrm{g} / \mathrm{ml})$ \\
\hline & 1000 & 10 & $10 \pm 0$ & \\
\hline & 100 & 10 & $10 \pm 0$ & \\
\hline & 10 & 10 & $10 \pm 0$ & \\
\hline \multirow[t]{7}{*}{ CSA } & 7.5 & 10 & $10 \pm 0$ & $2.3 \pm 0.16$ \\
\hline & 5 & 10 & $9.67 \pm 0.58$ & \\
\hline & 2.5 & 10 & $06 \pm 1$ & \\
\hline & 1.25 & 10 & $03 \pm 1$ & \\
\hline & 1000 & 10 & $10 \pm 0$ & \\
\hline & 100 & 10 & $10 \pm 0$ & \\
\hline & 10 & 10 & $9.8 \pm 0.76$ & \\
\hline \multirow[t]{4}{*}{ CST } & 7.5 & 10 & $7 \pm 0.5$ & $5.23 \pm 0.34$ \\
\hline & 5 & 10 & $5 \pm 0.5$ & \\
\hline & 2.5 & 10 & $2.9 \pm 0.36$ & \\
\hline & 1.25 & 10 & $1 \pm 0.14$ & \\
\hline
\end{tabular}

Key:

CSA $=$ Crude Saponins of Achillea wilhelmsii.

$\mathrm{CST}=$ Crude Saponins of Teucrium stocksianum. 

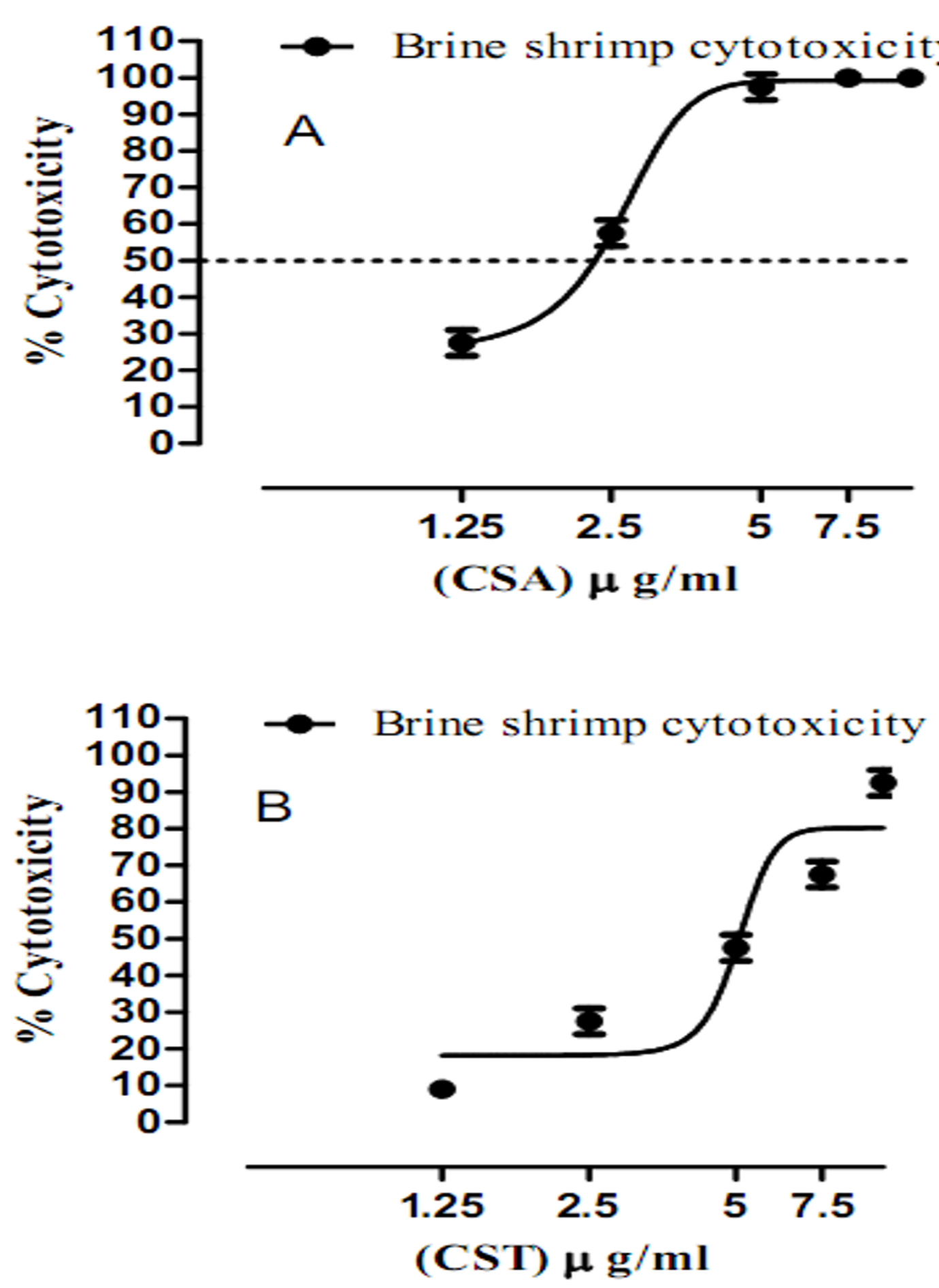

Figure 1 Cytotoxic activity of crude saponins of Achillea wilhemsii and Teucrium stocksianum. (A): Cytotoxic activity of crude saponins of Achillea wilhelmsii (CSA). (B): Cytotoxic activity of crude saponins of Teucrium stocksianum (CST). 
Table 2 Results of anthelmintic activity of crude saponins of Achillea wilhelmsii and Teucrium stocksianum

\begin{tabular}{|c|c|c|c|c|c|c|c|}
\hline \multirow{3}{*}{ Sample/Groups } & \multirow{3}{*}{$\begin{array}{l}\text { Conc. } \\
\mathrm{mg} / \mathrm{ml}\end{array}$} & \multicolumn{4}{|c|}{ Time taken for paralysis (P) and death (D) in minutes } & & \\
\hline & & \multicolumn{2}{|c|}{$\begin{array}{l}\text { Pheretima posthuma } \\
\text { (Earthworm) }\end{array}$} & \multicolumn{2}{|c|}{$\begin{array}{l}\text { Raillietina spiralis } \\
\text { (Tapeworm) }\end{array}$} & \multicolumn{2}{|c|}{$\begin{array}{l}\text { Ascaridia galli } \\
\text { (Roundworm) }\end{array}$} \\
\hline & & (P) & (D) & (P) & (D) & $(\mathrm{P})$ & (D) \\
\hline & 10 & 24 & 56 & 28 & 55 & 21 & 53 \\
\hline \multirow[t]{3}{*}{ CSA } & 20 & 17 & 47 & 17 & 40 & 16 & 39 \\
\hline & 40 & 09 & 26 & 11 & 25 & 11 & 28 \\
\hline & 10 & 27 & 59 & 28 & 56 & 24 & 52 \\
\hline \multirow[t]{2}{*}{ CST } & 20 & 20 & 48 & 19 & 42 & 18 & 40 \\
\hline & 40 & 11 & 27 & 14 & 27 & 12 & 27 \\
\hline Albendazole & 10 & 19 & 51 & 19 & 53 & 12 & 37 \\
\hline Piperazine citrate & 10 & 17 & 50 & 16 & 49 & 10 & 34 \\
\hline Negative control & - & - & - & - & - & - & - \\
\hline
\end{tabular}

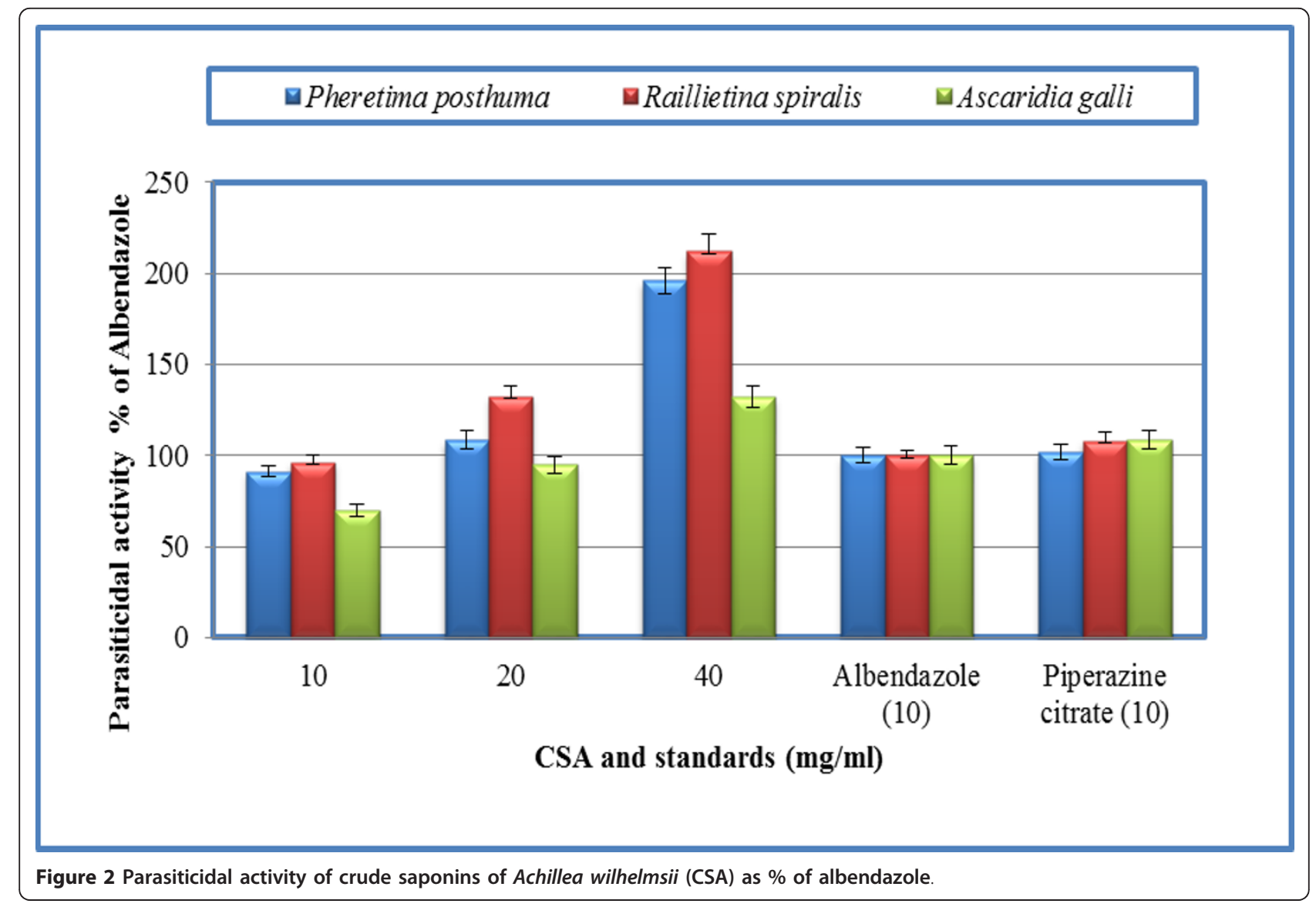




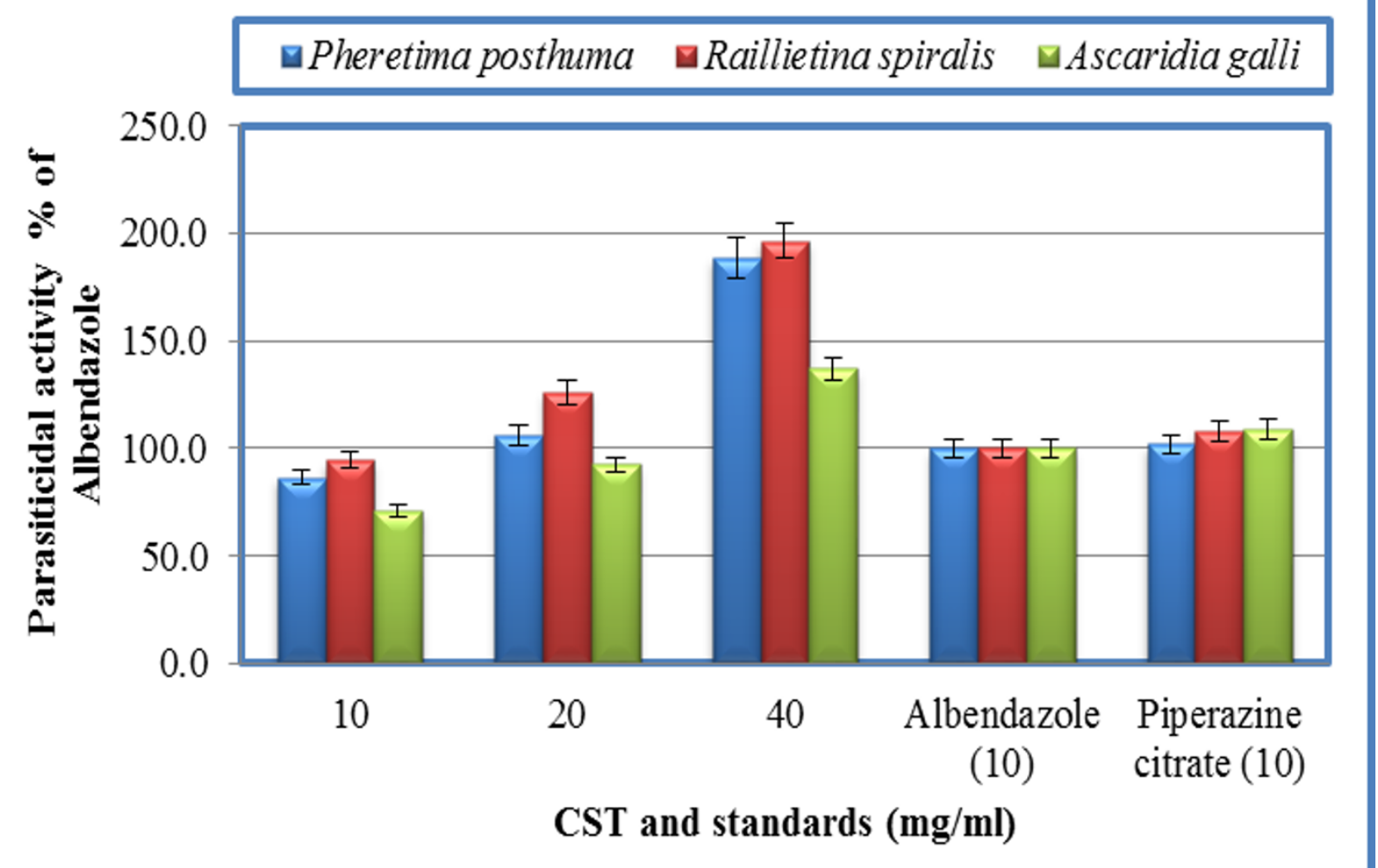

Figure 3 Parasiticidal activity of crude saponins of Teucrium stocksianum (CST) as \% of albendazole

\section{Acknowledgements}

The authors want to thank the higher education commission of Pakistan for providing budget for strengthening of pharmacology laboratory at Department of Pharmacy, University of Malakand.

\section{Author details}

${ }^{1}$ Department of Pharmacology, Institute of Basic Medical Sciences, Khyber Medical University, Peshawar, KPK, Pakistan. '2Department of Pharmacy, University of Malakand, Chakdara, Dir, KPK, Pakistan. ${ }^{3}$ Department of Biotechnology, University of Malakand, Chakdara, Dir, KPK, Pakistan.

\section{Authors' contributions}

NA participated in writing manuscript and data interpretation. The research scholars were also guided for laboratory work. SWA participated in brine shrimps study and data acquisition. IS participated in data acquisition. GA participated in data acquisition. MG helped in literature survey and data acquisition of anthelmintic activity. IK helped in data acquisition of anthelmintic activity. All authors read and approved the final manuscript.

\section{Competing interests}

The authors declare that they have no competing interests.

Received: 28 August 2011 Accepted: 3 November 2011 Published: 3 November 2011

\section{References}

1. Hostettmann K, Marston A: Saponins. Chemistry and Pharmacology of Natural Products. Cambridge University Press. Australia; 1995, 584.

2. Chen YF, Yang CH, Chang MS, Ciou YP, Huang YC: Foam Properties and Detergent Abilities of the Saponins from Camellia oleifera. Int J Mol Sci 2010, 11:4417-25.
3. Bruneton J: Pharmacognosy, Phytochemistry, Medicinal Plants. 2 edition. Lavoisier Publishing; Paris, France; 1995.

4. Price KR, Johnson IT, Fenwick GR: The chemistry and biological significance of saponins in foods and feeding stuffs. CRC Crit Rev Food Sci Nutr 1987, 26:127-35

5. Oakenfull D: Saponins in food-A review. Food Chem 1981, 7:19-40.

6. Martin RS, Briones R: Industrial uses and sustainable supply of Quillaja saponaria (Rosaceae) saponins. Econ Bot 1999, 53:302-11.

7. Takagi K, Park EH, Kato H: Anti-inflammatory activities of hederagenin and crude saponin isolated from Sapindus mukorossi Gaertn. Chem Pharm Bull 1980, 28:1183-88.

8. Huang HC, Liao SC, Chang FR, Kuo YH, Wu YC: Molluscicidal saponins from Sapindus mukorossi, inhibitory agents of golden apple snails, Pomacea canaliculata. J Agric Food Chem 2003, 51:4916-19.

9. Tamura Y, Mizutani K, Ikeda T, Ohtani K, Kasai R, Yamasaki K, Tanaka O: Antimicrobial activities of saponins of pericarps of Sapindus mukurossi on dermatophytes. Nat Med 2001, 55:11-16.

10. Corea G, Fattorusso E, Lanzotti V, Capasso R, Izzo AA: Antispasmodic saponins from bulbs of red onion, Allium cepa L. var. Tropea. J Agri Food Chem 2005, 53:935-40.

11. Yuan CS, Wang CZ, Wicks SM, Qi LW: Chemical and Pharmacological Studies of Saponins with a Focus on American Ginseng. J Ginseng Res 2010, 34(Suppl 3):160-67.

12. Seth R, Sarin R: Analysis of the Phytochemical Content and Anti-microbial Activity of Jatropha gossypifolia L. Arch Appli Sci Res 2010, 2(Suppl 5):285-91.

13. Lv X, Qiu S, Sun X, Li Z: Preliminary Study on the Capability of Antioxidation and Scavenging Free Radicals of Sasanqua saponins. Sci Food 2005, 11:86-90.

14. Pal D, Sannigrahi S, Mazumder UK: Analgesic and anticonvulsant effects of saponin isolated from the leaves of Clerodendrum infortunatum Linn. in mice. Ind J Exp Biol 2009, 47:743-47. 
15. Sparg SG, Light ME, Staden J: Biological activities and distribution of plant saponins. J Ethnopharmacol 2004, 94:219-43.

16. Sharififar F, Mohammadi SM, Arabnejad M: Immunomodulatory activity of aqueous extract of Achellia wilhelmsii C. Koch in mice. Ind J Exp Biol 2009, 47:668-71.

17. Ali N, Shah SWA: Antispasmodic activity of Teucrium stocksianum boiss. Pak J Pharm Sci 2011, 24(Suppl 2):171-74

18. Dande PR, Talekar VS, Chakraborthy GS: Evaluation of crude saponins extract from leaves of Sesbania sesban (L.) Merr. for topical antiinflammatory activity. Int J Res Pharm Sci 2010, 1(Suppl 3):296-99.

19. Meyer BN, Ferrigni NR, Putnam JE, Jacobsen LB, Nichols DE, Mc Laughlin JL: Brine Shrimp: A convenient general bioassay for active plant constituents. Planta Med 1982, 45:31-34.

20. Parida S, Patro VJ, Mishra US, Mohapatra L, Sannigrahi S: Anthelmintic potentials of crude extracts and its various fractions of different parts of Pterospermum Acerifolium Linn. Inter J Pharma Sci Rev Res 2010, 1 (Suppl 2):107-11.

21. Rehman AU, Mannan A, Inayatullah S, Akhtar MZ, Qayyum M, Mirza B: Biological evaluation of wild thyme (Tymus serpyllum). Pharm Biol 2009, 47(Suppl 7):628-633.

\section{Pre-publication history}

The pre-publication history for this paper can be accessed here:

http://www.biomedcentral.com/1472-6882/11/106/prepub

doi:10.1186/1472-6882-11-106

Cite this article as: Ali et al:: Cytotoxic and anthelmintic potential of crude saponins isolated from Achillea Wilhelmsii C. Koch and Teucrium Stocksianum boiss. BMC Complementary and Alternative Medicine 2011 11:106

\section{Submit your next manuscript to BioMed Central and take full advantage of:}

- Convenient online submission

- Thorough peer review

- No space constraints or color figure charges

- Immediate publication on acceptance

- Inclusion in PubMed, CAS, Scopus and Google Scholar

- Research which is freely available for redistribution

Submit your manuscript at www.biomedcentral.com/submit 